\title{
Thereby Hangs a Tail: Jonson's The Devil Is an Ass and Stage Representations of Devil-Servants
}

\begin{abstract}
This article considers an ambiguity concerning the stage presentation of Pug, the inept devil-servant of Ben Jonson's The Devil Is an Ass, and explores the implications that 'complete' or 'partial' costume changes have for how an audience interprets the character, and how this apparent visual ambiguity may have been resolved by cosmetics and/ or through the performance of a specific King's Men actor. The article concludes with a comparison of 'devilish servant-types' in Othello and The Changeling and argues that these three plays articulate early modern insecurities about the servant through an explicit association between the servile and the demonic.
\end{abstract}

Despite his declared distaste for the 'fools and devils and those antique relics of barbarism' found within the English dramatic tradition, ${ }^{1}$ Ben Jonson's witty mockery of devil and morality plays within his 1616 play The Devil Is an Ass indicates a clear knowledge of, and even 'nostalgia' for, these native dramatic forms. ${ }^{2}$ In Jonson's play the minor demon Pug convinces Satan that he can be entrusted with a mischief-making mission to London. Satan has his reservations - he worries that Pug is 'too dull a devil to be trusted' with the perils of the city, and he dismisses out of hand his underling's request to take a 'dotard' Vice with him $(1.1 .26,76)$ - but he permits the journey on two conditions: firstly that Pug inhabit the body of a 'handsome cutpurse hanged at Tyburn', and secondly that he bind himself to the first man he comes across (140, 151-2). Pug duly complies with both of these stipulations, and upon arriving in London dresses himself in clothes stolen from a servant and, in a moment of sartorial confusion that betrays his demonic naivety, a pair of ladies' shoes 'with a pair of roses / And garters' belonging to a prostitute (5.1.43-4). Upon entering the service of the foolish squire Fitzdottrel, however, Pug finds all his devilish intentions come to naught, and after a series of disasters - during which his infernal origins are not believed,

Tom Harrison (tom.harrison@ncl.ac.uk) is a teaching associate in the school of English literature, language and linguistics, Newcastle University, UK. 
and he is beaten, conned, spurned, prodded, and poked by the mortals he encounters - he prays to return to his minor role in Hell. Satan eventually appears to put Pug out of his misery, but not before he denounces Pug as a 'scar' upon the name of demonkind who has achieved nothing against wily Londoners who have 'proved the better fiends' $(5.6 .60,62)$. In an inversion of the conventional stage picture, Pug is carried off on the Vice Iniquity's back, the image enforcing the extent of the demon's failure: 'The Devil was wont to carry away the evil; / But now the evil out-carries the Devil' (76-7).

Audiences of the time shared Jonson's familiarity with devil plays: Christopher Marlowe's Doctor Faustus, its B-text (published 1616) an exact contemporary with Jonson's play, still loomed large on the theatrical landscape, and its continuing commercial dominance was so great that all devil plays produced after its putative first performance in 1588 could not escape reference to it, even if - as in Jonson's case - such references took the form of parody. ${ }^{3}$ Indeed, Alan Dessen sees Jonson's play steering a course between contemporary Faustus-inspired devil plays and earlier moralities, picking up the 'serious diabolic action' not only from Marlowe but from Thomas Dekker's If This Be Not a Good Play, the Devil Is in It (performed 1611-12); echoing the knockabout comedy and demon-duping of The Merry Devil of Edmonton (performed 1599-1604); imitating the useless devils Belphagor and Akercock in William Haughton's The Devil and His Dame (performed ca 1593-1601); ${ }^{4}$ as well as revisiting the conventional byplay between Vice and devils found in pre-Marlovian moralities such as Ulpian Fulwell's Like Will to Like (performed 1562-8) and Robert Wever's Lusty Juventus (performed ca 1551). ${ }^{5}$ Such imitation and distortion of earlier works is deliberately self-conscious (the Prologue directly references Dekker's play and The Merry Devil [20, 26]), ${ }^{6}$ and point to the fact that the characters and conventions associated with devil plays were still bankable theatrical elements in 1616 .

Despite his protestations to the contrary, Jonson clearly saw that the demonic continued to have dramatic potential, and the ease with which his comedy moves within the tropes of the devil play sub-genre suggests that he paid more attention to these works than he would like his audiences to think. Pug is well-versed in his devil narratives as well, and he claims to Satan that his exploits on Earth will produce 'more upon't, / Than you'll imagine' (1.1.39-40). His ambitions are for the physical and spiritual corruption of whomever he chances across, emulating the nefarious achievements of Mephistopheles, who despite being bound to Faustus never forgets that he is 'servant to great Lucifer', and claims an influence in damning his earthly master (B-text $1.3 .38 ; 5.2 .96-7){ }^{7}$ the three devils of Dekker's If This Be Not a Good Play, who succeed in swelling Hell's commonwealth with the 
souls of a greedy merchant and the corrupt friars of a priory, all of whom 'Sinck downe, above flames' at the play's close $(5.3 .149 \mathrm{sd}) ;{ }^{8}$ or even the Devil in Barnabe Barnes's The Devil's Charter (performed 1607), who poisons Pope Alexander to hasten his passage to Hell, and who mocks this same character before his death by appearing dressed in the pope's papal robes (5.6.3068-9).9 Unfortunately though, Pug finds himself cast in the wrong type of play to get even close to these diabolic achievements. One must not forget that the The Devil owes an equal debt to city comedy, a genre that focuses on fools being duped, lovers flouting parental authority, and crafty servants siding with young masters over old, and which serves as a secularized, modernized outlet for the carnivalesque, inversionistic energies we find in the English moralities and Roman new comedies. Despite the demon's best efforts, Pug quickly establishes himself as a gull rather than a guller in this strange environment. ${ }^{10}$ Pug's request for a Vice to 'practise' with on Earth establishes him as a trickster figure of the morality/devil play tradition (1.1.38), but he soon abandons these grand schemes for the more modest aim to 'make this master of mine cuckold' (2.2.13); ultimately, he fails in this too, and when set against a more streetwise set of Londoners he finds himself cast as the country bumpkin in another's city comedy. ${ }^{11}$

The Devil engages with both the devil play and city comedy through the 'literary imperialism' Robert Watson detects in Jonson's dramaturgy; the playwright asserts creative dominance over his rivals by ironizing and parodying their material, and placing what he sees as the theatre's complacent reliance on 'hackneyed traditions' in the minds of his foolish characters, who are purged of their humour by their play's end. ${ }^{12}$ Aside from mocking the methods of his contemporaries, Jonson also consistently undermines the expectations of his audiences, whose assumptions about plot are habitually 'aroused and overruled' in plays that treat unthinking spectators as equally foolish as the characters they observe. ${ }^{13}$ From this perspective, Pug is an appropriate audience proxy: his confusions are our own, for despite the demon's high ambitions his great tricks never materialize, and the narrative of demonic corruption that he imagined is quickly exposed as naive. Jonson's efforts in The Devil are both a testament and a challenge to the sophistication of his contemporary London audience, which he presents as impervious to the old traditions that Satan and his devils represent. This is a fact that the arch-fiend himself admits: the Londoners of 'six hundred and sixteen' are more than capable of creating their own vices, 'Stranger and newer' than any brought from Hell (1.1.102), and any demon worth their sulphur needs to offer temptations more 'extraordinarily subtle' than those Iniquity and his jangling fourteeners present (116). 
In this essay I use Jonson's continuing interest in unsettling generic and audience expectations as an inspiration and justification for an admittedly speculative, but nevertheless important, exploration of how the playwright may have intended to portray his devil-servant Pug onstage. The silence on how Pug achieves a change of appearance between his first scene in Hell (1.1) and his second in London (1.3) is curious for a play-text that seems so keen on documenting stage action for its readers - a balcony scene between the Wittipol and Mrs Fitzdottrel, it notes, 'is acted at two windows, as out of two contiguous buildings', and as the scene advances the gallant 'grows more familiar in his courtship, plays with her paps, kisseth her hands, etc.' (2.6.40, $70 \mathrm{sds}) .{ }^{14} \mathrm{I}$ make suggestions as to how the uses of costume, cosmetics, or a specific actor have the potential to produce different audience responses to the character and to the play at large. A consideration of these effects is not trivial, as Jonson's elision of devil and servant is a microcosm for the play's comic exploration of genre. Indeed, the stage servant is an apt figure for Jonson's trans-generic experiment, as their presence in plays of the period spans tragedy and comedy, their ubiquity onstage reflecting a social reality in which servants were present in all but the poorest of households, and their function within the plays that contained them often highlighted their potential both for subversion and maintaining the status quo. ${ }^{15}$ In the second part of my discussion I turn briefly to other depictions of devious servants and two 'devil-servant-types' in Othello (performed ca 1601-4) and The Changeling (performed 1622). Whereas Jonson deploys the hybrid devil-servant to comic effect, the character also has tragic resonances, and the repeated appearance of the character across dramatic genres articulates wider concerns about how the figure of the servant is simultaneously emblematic of obedience and subversion. 16

Despite Pug's dual role as devil and servant, previous commentators have remained curiously vague about how this character could have been represented onstage. Peter Happé, the play's Revels editor, asserts that Pug and Satan 'should appear as devils' in 1.1, ${ }^{17}$ an appearance that Anthony Parr claims involved the 'traditional costumes of horns, mask, and tail', 18 after which Pug, according to John D. Cox, 'doffs his devil suit' to inhabit the cutpurse's body and put on the servant Ambler's clothes and his lady's shoes. ${ }^{19}$ The prospect of a change in appearance between Pug's scenes in Hell and on Earth seems reasonable - especially as Pug now presumably inhabits the body of the 'handsome cutpurse' but a question that stands unanswered is whether this change is complete (the Pugactor removing his devilish attire in exchange for a new appearance) or partial (the Pug-actor putting a new costume over his devilish one). Whether Jonson signalled Pug's dual identity through visual signifiers or required his audiences to make the 
association themselves, he encourages an explicit connection between servant and devil in his play. Such an association links with the idea of the conceptual blend, which Michael Booth describes as 'an integration that has not been, or cannot be, completed, something in a state of unresolved duality, showing two natures at once', and which holds in its irresolution the paradox of identification and difference that is apparent in Jonson's devil-servant. ${ }^{20}$ In this reading Pug becomes much more significant to the play's purpose than his onstage role would suggest, as his character captures the spirit of seeming one thing but being another that is so apparent in The Devil's other characters and in its status as a trans-generic play.

I must acknowledge, however, that the lack of consensus on how early modern actors 'appeared' as devils does not make it easy to answer the question about Pug's appearance. ${ }^{21}$ Nevertheless, performance records and surviving play-texts can provide clues: Cox and Martin Wiggins note stock items of costume and make-up that included feathered wings, masks, horns, blackened or reddened faces, robes, prosthetic noses, shaggy hair, and long nails, and some playwrights are even helpful enough to include mottos on their characters' costumes that proclaim their demonic identity. ${ }^{22}$ Aesthetic and ideological interests influenced the variation in how devils were presented onstage, and more prosaically, a playing company's financial and costuming resources no doubt also exerted an influence, reflecting the fact that iconographical depictions of the Devil and his minions were themselves diverse. ${ }^{23}$ Regardless of the specifics of costume and makeup from play to play, the dominant emphasis was clearly that stage devils were intended to be grotesque: thus Coreb in The Merry Devil of Edmonton appears in a 'horrid shape' (scene 1); ${ }^{24}$ Shackle-Soul in If This Be Not A Good Play is a 'frightfull shape' (4.4.38 sd); the opening of The Devil's Charter calls for a 'divill in most ugly shape' (Prologue 40); and Mephistopheles, most famously of all, is ordered offstage by Faustus for appearing 'too ugly' at his first appearance (B-text 1.3.25). One should certainly not infer too much about what the well-known image from the title page of the B-text edition of Doctor Faustus (which appears to depict Faustus and Mephistopheles) can tell us about how those two character types were represented onstage, but strikingly the devil who appears in the bottom right corner of the image - blackened, tailed, possibly feathered or hairy, certainly 'horrid' - appears to have many of the visual characteristics identified above.

Documentary evidence clearly shows that players had a range of options to draw upon when costuming their demons, and judging from this evidence dramatists regularly took the opportunity to make these characters as grotesque as possible. Jonson may have wanted his devils to be similarly striking in his opening scene, and even if the costume were particularly elaborate, the Pug-actor would probably 
have had time to effect a complete costume change. Pug has approximately fifty lines after being dismissed by Satan in 1.1 before he appears to Fitzdottrel in 1.3, during which time he could have removed his devilish attire in exchange for his new cutpurse's body and purloined clothes. If the transformation were complete though, Jonson risked making Pug's next entrance confusing, as the costume change contains a number of unexpected elements that prove difficult to interpret according to the staging conventions of the time. Early modern dramaturgy relied heavily on costume to provide visual cues to the audience about a character's type and social status, a practice that was made all the more necessary by doubling of roles. ${ }^{25}$ If a character did change costume, playwrights had to ensure their audiences understood that the actor appearing onstage in different clothing was still playing the same character, a requirement achieved either by having the actor change onstage, or having the character or other characters announce the change either before it happens or as soon as they next appeared. ${ }^{26}$ Jonson comically references this use of costume as an index to character when he has Fitzdottrel examine Pug's feet 'over and over' because he believes the roses attached to Pug's (women's) shoes are 'big enough to hide a cloven foot' (1.3.9 sd; 1.3.9). As an ardent theatre-goer himself, Fitzdottrel would have known that such an embellishment frequently served this purpose - the suggestion that rose decorations hide a cloven hoof appears in William Shakespeare's Othello, John Webster's The White Devil (1612), and George Chapman's Caesar and Cleopatra (1633). ${ }^{27}$ Here is a subtle prompt to Pug's demonic nature for the more alert audience member, but those who miss this detail and instead notice only an actor reappearing onstage looking different from what's expected could quickly find themselves just as confused as Fitzdottrel.

In fact, confusing the audience may have been Jonson's intention in these opening scenes. Cutpurses and similar criminal types made frequent appearances on the Renaissance stage, so an audience primed to look out for Satan's 'handsome cutpurse' could have relied on visual appearances (including costume and props) to identify the devil in the next scene. ${ }^{28}$ What is crucial, though, is that while Satan orders Pug to 'take a body ready-made' (1.1.135), he does not include the hanged man's clothes, instead instructing him to 'employ your credit with the hangman, / Or let our tribe of brokers furnish you' (142-3). If we are to follow the idea of a complete costume change, we must accept that the audience can grapple with the interpretive difficulty not only of the Pug-actor, as Cox puts it, 'doffing his devil suit' from the opening scene, but also of the character reappearing wearing clothes that do not correspond to Satan's description, with no apparent explanation as to the origin of this new costume; indeed, Jonson's audience has 
to wait until 5.1 to discover the origin of Pug's clothing, when Ambler reveals it was snatched while he sought 'To gi' my body a little evacuation' with a prostitute (5.1.22). Perhaps performance mitigates this costume issue as Pug establishes his devilish nature early on, when after his claims of being 'born a gentleman' and wanting to enter Fitzdottrel's service out of 'love' rather than for financial reward are rejected, he resorts to confessing that he is, in fact, 'a devil' to attract the other's interest $(1.3 .2,20,25)$. Even if this costume is alleviated in performance, though, Jonson breaks with convention, because in other instances of a devil character making a complete change in costume the nature of this change is made explicit to the audience either before or as soon as they enter. A notable example of this technique is found in the Doctor Faustus B-text, which first sees Mephistopheles enter as a 'dragon' (1.3.23 sd), to which Faustus responds:

I charge thee to return and change thy shape.

Thou art too ugly to attend on me.

Go, and return an old Franciscan friar;

That holy shape becomes a devil best.

We find the same technique deployed in Dekker's If This Be Not a Good Play, one of the 'new plays' Jonson cites in his prologue, and which he presumably had in mind as he wrote (Prologue 20). Dekker also begins his play in Hell, and has Pluto order three of his devils to disguise themselves in 'a Courtiers shape', a 'Friers graue habit', and 'In trebble-ruffes like a Merchant' so they can travel to Earth to acquire new souls 'T'uphold hells Kingdome' (If This Be Not, 1.1.78, $81,82,57)$, and the three devil-actors have approximately ten lines in which to reappear in 'shapes transformde' (93). In both examples Marlowe and Dekker demand a quick change in appearance in their actors, but having primed their audiences for a substantial 'transformation' these devil-characters could likely mark the transition between their demonic and human selves with a complete costume change, allowing both playwrights to cast satirical comment on the roles the devils have now assumed (friar, merchant, and courtier: all familiar figures of corruption on the English Renaissance stage) while simultaneously obeying theatrical expectation.

Jonson's Satan references Pug's 'handsome cutpurse' body, which also seems to conform to this convention; crucially, however, neither a clear costume change nor any acknowledgement that the Pug-actor plays the same character marks the 1.3 transition. Instead, Jonson's devil appears in clothing that one would not automatically connect with his new cutpurse body (he has stolen his clothes from a servant and his shoes from that servant's lady companion, rather than acquiring 
them from the hangman or the 'tribe of brokers'), and the audience only becomes certain that the Pug-actor is still performing as the devil because the Pug-character tells them this during the scene itself. We must always accept that dramatists are not completely beholden to staging conventions that precede them, but if Jonson did break with expectations he was likely to have confused his audience's recognition of the Pug-actor's transition between 1.1 and 1.3. The extent of Pug's costume change would have had a significant impact on the audience's perception of the character in subsequent scenes. If the costume change were complete and unaccompanied by character comment, Jonson ran the risk of making Pug's identity in 1.3 initially ambiguous, and would require the audience to, as it were, 'add the horns' to the character at his later appearances. We must not discount this visual confusion as a deliberate choice, as Jonson may well have seen the benefit in giving his audience members a moment of interpretive uncertainty at Pug's first appearance, with the deliberate mixing of visual signals that a complete costume change would produce throwing them into the same act of misreading as Fitzdottrel. The second option is that the Pug-actor could effect a partial costume change, with at least a vestige of his devil costume remaining. A precedent may exist for this practice, as Barnes's The Devil's Charter includes a devil who enters 'like a Poast' to tell the doomed Alexander that he has been 'sent with the wagon of blacke Dis, / To guide thy spirit to the gates of death' (5.6.3247, 3255-6). ${ }^{29}$ The grotesque incongruity of the devil's task and his quotidian earthly appearance makes Alexander's fall grimly comic; indeed, the audience had just received a more profound example of devil-human transvestism when the Pope 'draweth the Curtaine of his studie where he discouereth the divill sitting in his pontificals' (3068-9), an image that is all the more startling because it replicates an earlier image of Alexander sitting, Faustus-like, 'in his study with bookes, coffers, his triple Crowne upon a cushion before him' (1.4.325-6). In Marlowe, Dekker, and Barnes's plays, the dressing of actors in a mixture of devilish and earthly apparel underlines the connection between worldly preoccupations and spiritual damnation. We can imagine Jonson tuning this effect to a comic key in The Devil, only here the visual blend speaks less to the close relationship between world and spiritual corruption and more to Pug's manifest unsuitability for, and increasing discomfort with, his newfound role.

Clothing is only one element of a character's appearance, however, so another solution to the Pug-actor's quandary may lie in the use of black cosmetics, one of the most consistent visual signifiers for the demonic on the early modern stage. The association between the Devil and blackness was proverbial, ${ }^{30}$ and can be traced back at least to the medieval period in Christian iconography, ${ }^{31}$ with records 
suggesting that from their earliest appearances on the English stage demon-actors appeared with blackened faces or wearing some kind of mask or demonic head. ${ }^{32}$ The Pug-actor would have had a reasonable amount of time between his Hell scene and his reappearance in 1.3, so the use of an easily-removed demon mask or head would be possible, although anything that obscured the actor's face too much would again lead the audience into the sort of difficulties of recognition mentioned above. Virginia Mason Vaughan observes that by the late sixteenth century a shift from 'display to performance' of black-faced characters (particularly devils and moors) meant that the masks used to represent them in earlier theatre were no longer suitable for these more nuanced and narratively-central characters. ${ }^{33}$ Like the late-sixteenth-century stage moor, Jonson's Pug is clearly more subtly-drawn than his predecessors in the mystery and morality plays, and a devil mask that obscured too much of the Pug-actor's face could have reduced his effectiveness as a character on an English stage that, in marked contrast to continental traditions like the Italian commedia dell'arte, was not accustomed to masking its comic actors.

By contrast, black make-up had the virtue of leaving the Pug-actor readily identifiable but would have carried its own technical challenges. Richard Blunt's experiments with early modern recipes for black-face cosmetics demonstrate that there existed a variety of effective techniques to depict a black-faced character onstage. According to one recipe, an actor's skin can be darkened by applying a pigment derived from black walnuts over a base layer of egg white or tallow; the resultant mixture is dark-brown, surprisingly resilient, but takes some effort to remove completely. ${ }^{34}$ If Jonson's Pug-actor were covered in this sort of cosmetic - perhaps with a pigment layer of soot, as Vaughan suggests, in order to achieve a darker skin tone ${ }^{35}$ - the fifty lines between his exit at 1.1 and reappearance at 1.3 may not have provided enough time to remove it completely. An alternative possibility is that the Pug-actor's face was blackened only with a layer of soot for the Hell scene; as Blunt points out, this material would have been less durable but also challenging, as it would require 'any actor wearing it to limit physical interaction because it could smudge easily onto others. ${ }^{36}$ This second option is perhaps the most practical, although, as already noted, such an abrupt change in skin pigmentation without acknowledgement would have left an audience uncertain whether the Pug-actor was performing another role in 1.3.

But what if the Pug-actor did not even attempt to remove the make-up, and instead kept his dark colouring for the rest of the play? Such a decision would have avoided the technical difficulty of removing stubborn cosmetics, and keeping his face blackened through his hellish and earthly travels would visually establish 
that the Pug-actor's demonic nature had not changed. Aside from its associations with devilry, Robert Hornback highlights that blackness was also connected with folly, ${ }^{37}$ so a black-faced Pug would have brought an additional benefit by capturing both the demonic and idiotic aspects of his personality during his earthly sojourn. Jonson's play is preoccupied with make-up and artifice — as foregrounded in Lady Tailbush's salon scene of 4.1, in which Pug features as a not-so-willing participant - so the presence of a character whose cosmetics do represent who he really is, but whose devilishness appears more 'painted on' with each encounter with his human tormentors, provides an ironic sidelight on the typical Jonsonian presentation of cosmetics masking one's true nature. ${ }^{38}$

As a final point, details concerning the personnel working in the King's Men when The Devil premiered might provide another solution to this interpretive difficulty. Only one actor can confidently be connected to Jonson's play: Dick Robinson, who was well-known for portraying female parts, and whose skill is capitalized on through his likely performance as Wittipol, a young gallant who impersonates a Spanish Lady because, according to the conceit of the play, 'Robinson' himself could not be acquired. The Robinson-Wittipol link suggests that Jonson was willing to foreground metatheatrical connections between actor and character, so we could also make a tenuous speculation about Jonson's devil-servant, for the name 'Pug' - which could in the period mean a term of endearment for a plaything or a pet, a courtesan, a ship's boy, or a servant, ${ }^{39}$ and was a synonym for spritely creatures like Puck or Robin Goodfellow — gives us a hint about the sort of actor who may have played him. 'Pug' sounds like a diminutive that may be applied to a small or younger actor, and it may have been the size of Jonson's actor that allowed audiences to note the transition between two distinct costumes. Evidence from the text supports a case that Jonson may have intended a specific actor to play his hapless demon. The play's opening is clear on establishing Pug's juniority: he is a 'petty puny devil' (1.1.5) in comparison to his master Satan, and to the Vice Iniquity he is a 'child' $(55,69 ; 5.6 .13,20,23)$, a 'boy' $(1.1 .68,76 ; 5.6 .14,21)$, and a 'baby' (16). To be sure, these appellations may have as much to do with the seniority of Pug's interlocutors - Satan is lord of Hell, and Iniquity is a creaking revenant from a bygone age - but significantly the association between the character and youthfulness pursues the devil into his new body. Fitzdottrel's desire to see the Devil in a 'brave young shape' immediately before Pug appears gains comic impact if the Pug-actor really fits this description (1.2.52), and this anticipation of a youthful actor is further suggested at the close of the play when the keeper of Newgate is amazed at the disappearance from his custody of the 'young cutpurse' who, interestingly, 'every one of us know[s]' 
(5.8.126). Pug himself is keen to promote his youthful credentials: his claim to Fitzdottrel that he is a 'younger brother' from a rich family says nothing specific about age but clearly indicates his juniority (1.3.3), and he plays on this suggestion further when he admits to Mistress Fitzdottrel that he is not in due symmetry the man / Of that proportion ... To boast a sovereignty o'er ladies' (2.2.120-1, 124), and promises her that he will be 'your slave, / Your little worm ... your fine monkey; / Your dog, your jack, your Pug' (126-8).

Jonson goes some lengths to establish Pug as a character small in social stature, and the descriptions of him as 'petty', child-like, and disproportioned would have added weight if the actor himself had been either younger or shorter than his fellows. Perhaps another clue is found in Satan's description of Pug's new body as 'handsome', which seems an odd inclusion unless Pug's new incarnation was visually striking in some way. ${ }^{40}$ Even if one discounts a continuity of costume or cosmetics between Pug's presentation in 1.1 and the rest of the play, Jonson might have had an actor in mind whose appearance was recognizable enough even after a substantial costume change, and whose skill as a comic actor was such that an audience would be unlikely to think him to be doubling a role. From this perspective, the Keeper's claim to recognize the 'young cutpurse' carries metatheatrical weight and suggests that it was not just Dick Robinson that Jonson hoped his audience could identify onstage.

If indeed a young actor performed the role of Pug, the most compelling candidates I can identify from surviving documents concerned with the King's Men are Thomas Pollard, George Birch (or Burgh), and Richard Sharpe, all of whom were boy or young actors with the company around $1616 .{ }^{41}$ Pollard, who according to Bentley joined the company around 1615, tended to play comic parts, but the earliest record of him on a cast list dating from 1616-17 may indicate that he joined the company after The Devil's premiere. ${ }^{42}$ Birch was not only experienced in comic roles but may have been familiar to Jonson as he probably played Doll Common in a revival of The Alchemist and Lady Politic Would-Be in Volpone, both 'sometime between 1616 and 1619'. ${ }^{43}$ Richard Sharpe, who became John Heminges's apprentice on 21 February 1616, would have been around fourteen when the company first performed The Devil and was good-looking enough to be regularly cast in romantic roles; the fact that he played the Duchess in the 1620s revival of The Duchess of Malfi further indicates his skill as an actor, although he was not especially noted for playing comic parts. ${ }^{44}$

These three actors were young men at the time of The Devil's premiere and may have had the necessary physical attributes to play Jonson's 'puny' but 'handsome' devil. We should also not discount other actors in the company who were a 
little older, but who may have had the requisite physical characteristics and comic skill to perform the role. For instance, John Rice, John Underwood, William Ostler, Nathan Field, and William Eccleston (or Eglestone), were all in their twenties by 1616 and as boy players had established themselves as regular lead female characters, which is itself an endorsement of their actorly skill. ${ }^{45}$ Of these actors William Ecclestone is especially intriguing: aged twenty-five in 1616, he may have specialized in comic roles and had already performed in Jonson's The Alchemist (1610-11) as Kastril - a character who, similar to Pug, is also described in youthful terms as 'young' (3.4.22), a 'boy' (3.3.82; 4.2.13-14) and a 'child' (4.2.22). ${ }^{46}$ Ecclestone must have been around twenty years old when he performed in The Alchemist, so the diminutives attached to Kastril may indicate that, even as an adult, he was shorter than the other players; if this is the case, he would have been a good option a few years later to play a role that required a similar stature but good comic sensibilities. Additionally, Wiggins, drawing on 'evidence and inference' in part from Thomas Middleton's A Chaste Maid in Cheapside, in which Ecclestone may have played Sir Walter Whorehound, suggests that the actor may have had red hair, a physical feature that was striking enough to be noted at the time, ${ }^{47}$ and (as long as Jonson's devils did not wear wigs) could have served as a marker between the 1.1 and 1.3 transitions.

The paucity of documentary evidence means too much speculation about the identity of the Pug-actor is unwise, ${ }^{48}$ but we cannot escape the historical reality that a King's Man did play Pug in 1616, and that the youth, appearance, and comic abilities of the actors listed above make them reasonable options as performers of Jonson's devil. If these actors were especially striking physically, if Jonson knew them personally, or if they were beginning to establish themselves as familiar faces in the company - thus making George Birch, Richard Sharpe, and William Ecclestone especially attractive candidates - we may have an answer to the mystery as to how Jonson could have potentially changed his character's appearance so profoundly without causing his audience undue confusion.

What is most important from the discussion above is that whether one favours a complete or partial costume change, or whether one supposes that the Pug-actor was familiar enough to be recognizable to the audience irrespective of what he wore onstage, I suggest that the overall effect is the same: audience members are expected, either by exercising their imaginations, identifying clues in costume or cosmetics, or recognizing the Pug-actor himself, to interpret the character they are watching onstage as a devil and a servant at the same time. This recognition is significant, as this blending of character in the (mind's) eye of the audience makes an implicit link between the traditional image of the treacherous devil 
and the servant, a figure who, due to the extensive impact of the servus callidus character type, had acquired a similar reputation for cunning and deviousness on the Renaissance stage. ${ }^{49}$

Servants were common sights in early modern households, and in their social status and function - both within and without a family, privy to intimate secrets yet expected to keep them - dramatists of the time found a character type that could fulfil a variety of supportive, disruptive, and destructive functions. Jonson had a particular fondness for depicting scheming servants in his city comedies witness Face of The Alchemist, and Musco/Brainworm of the quarto and folio versions of Every Man in His Humour — but his finest example of the genus is a character who can be most clearly connected with the morality/devil play tradition. Mosca, Volpone's 'fine devil', is judged 'the chiefest minister, if not plotter' of the play's 'lewd impostures' (Volpone 5.3.46, 5.12.108-9), and his soliloquy in praise of parasitism is especially noteworthy for his praise of himself as a 'subtle snake' who can 'change a visor swifter than a thought' (3.1.29). Taken together, these descriptions connect Mosca not only to the prelapsarian tempter but also to the stage tradition of disguise and trickery that was typically the province of the Vice; in Mosca's schemes we see the diabolic successes that Pug can only hope to achieve. The conflation of servant and demon in Volpone and The Devil seems appropriate to a period in which play demons were increasingly associated with the lower classes, an association that Cox sees as a marker of the age's 'shifting social attitude toward the indigent':

Officially understood before the Reformation as sanctified by their poverty, the poor gradually became the objects of suspicion and rejection. This shift in turn had a number of causes, some relating to religious secularisation: the enclosure of common lands that deprived many tenant farmers of their livelihood and increased the number of 'sturdy beggars', the dissolution of the monasteries, Protestant opposition to mendicant clerics, a decline in generosity because of reformed ideas about salvation through faith rather than good deeds. ${ }^{50}$

Pug's servile guise is therefore partly a contemporary trend, a diabolic reframing of wider fears surrounding insurrection or betrayal, either from below or from one's own family. ${ }^{51}$ The decades that surrounded The Devil were ones in which the domestic tragedy, the murder pamphlet, and the coney-catching text were all bestsellers, and this material repeated the same messages ad nauseam: that violence and treachery lurks within the family home, that the lower orders are not to be trusted, that a lack of clear division between social strata leads to chaos. ${ }^{52}$ 
Within this framework the servant maintained a contentious position. In their best light, servants represented proper hierarchical order, with reciprocal loyalty between master and servant reflecting the dynamic that should exist at the social and divine levels; at their worst, their ubiquity could take on a nightmarish quality, with a master's close proximity to and reliance upon his inferiors leaving him open to exploitation and abuse. ${ }^{53}$ As a result, Mark Thornton Burnett claims that the servant is a 'paradoxical figure, simultaneously slipping in and out of categories and fixed to a hierarchical order', and, unsurprisingly, for the writers and playwrights of the period they represented 'a convenient vehicle for testing the stability of early modern social formations. ${ }^{54}$ In many plays of the period we see servants deploying their liminal status to support, however dubiously, the interests of their superiors: thus we have Butler in George Wilkins's The Miseries of Enforced Marriage (performed 1606), who assists in reviving the fortunes of the Scarborow family through theft and trickery; Nicholas in Thomas Heywood's A Woman Killed with Kindness (performed 1603), who reports details of his mistress's affair to his master; even Bosola of Webster's The Duchess of Malfi (performed 1614), Vasques of John Ford's 'Tis Pity She's a Whore (performed ca 1629-33), and Reignald of Heywood's The English Traveller (performed ca 1633) pursue their murderous or mischievous agenda at the behest of a master or mistress figure. Numerous examples exist, however, of a servant's talents being deployed against their master's interests. The anonymous Arden of Faversham (performed ca 1590) provides a prime instance of these worries about servants and the attendant breakdown in familial and social order that their transgressions may imply, as Master Arden is betrayed by his wife Alice, the steward Mosby, and his own servant Michael, all of whom forget their obligations towards the man they owe their loyalty, either through marriage, social rank, or servile duty. The revelation of the murderers' identities - through a fortuitous fall of snow, a careless disposal of the murder weapons, and the post-mortem bleeding of Arden's corpse in the presence of his killers - is a sign that providence reasserts natural order at the play's close. Nevertheless, Michael's meek acquiescence to the murder of his master in his own home, and Alice Arden's subsequent invitation that 'Master Mosby, sit you in my husband's seat', ${ }^{5}$ represent a household in which social hierarchies have completely broken down.

A master's anxiety about insurrection from below could easily be inverted, of course, and for every Master Arden of Faversham there were presumably countless servants or servant-types who were abused or extorted by unscrupulous superiors. Shakespeare makes powerful dramatic use of this potential for extortion in Othello, for although the motivations behind Iago's actions are complex, they are 
partly inspired by Othello's promotion of Cassio over his ensign, an action that Iago views as going 'by letter and affection' rather than by the 'old gradation' of time served:

I follow him to serve my turn upon him.

We cannot all be masters, nor all masters

Cannot be truly followed. You shall mark

Many a duteous and knee-crooking knave

That, doting on his own obsequious bondage,

Wears out his time much like his master's ass

For naught but provender, and, when he's old, cashiered. $(1.1 .35-6,41-7)^{56}$

The 'curse of service' (34), as Iago sees it, is the reliance an underling has on their superior fulfilling their part of the social contract, which is by no means guaranteed; the ensign's talk of time slipping away, of the 'obsequious bondage' of service being regarded as little more than that of a beast of burden, and of finally being 'cashiered' - a word that, in the context, connotes less a withdrawal to a retirement home and more a final trip to the slaughter-house - all point to a working arrangement with the scales tipped firmly in favour of the powerful. Even Jonson's comedy gives us a hint of this ruthless attitude to employment, for after Fitzdottrel initially turns down Pug's service on the grounds that he already has a servant 'Who is my all, indeed; and from the broom / Unto the brush: for just so far, I trust him' (1.3.11-12), the squire quickly decides to 'turn away my tother man' when he realizes that Pug's offer will save him money (37).

In this final section I move beyond Jonson's play by briefly considering the conflation of devils and servant-types in the characters of Iago in Othello and DeFlores in The Changeling; the blend here is, as it were, in the opposite direction, for in both instances the emphasis is not so much on these characters being devils but on the appropriation of the language of devilry and the diabolic to describe their personalities and actions. ${ }^{57}$ I have deliberately chosen the word 'servanttypes' to describe these two characters, as Iago, at least, is not a 'servant' in the conventional sense; I follow Burnett in viewing Iago as servant-like in his relationship with Othello, and the ensign's desire for preferment, and his dissatisfaction at not receiving it, hinges on an expectation of the reciprocal forms of reward and service that can be found in the master-servant relationship. ${ }^{58}$

In Iago and DeFlores's hands, the concept of 'service' becomes less one of the ties that bind and more of the noose that throttles: the former wishes to 'serve my turn' upon Othello, and uses his intermediary position among many of the play's characters as the means to achieve this end. Following the murder of Alsemero, 
the latter's interpretation of 'service' takes on an increasingly sexualized meaning, with DeFlores using Beatrice-Joanna's implication in the crime to coerce her into bed with him..$^{59}$ Both characters manipulate the condition of service for their own purposes, and the language used to convey this manipulation is strikingly full of biblical resonances. In referencing Beatrice-Joanna's loss of her 'first condition' DeFlores invites comparison with the Fall (Changeling 3.3.138) - a comparison enforced later when he calls her 'the broken rib of mankind' (5.3.146) — and, as with Jonson's Mosca, descriptions of the servant as a 'serpent', a 'viper', and a 'basilisk' all evoke the reptilian antagonist of Genesis (1.1.110, 127; 3.3.165; 5.3.67). Iago, too, is described as a 'viper' (Othello 5.2.282), but his connection to the Satanic is even more explicit: once his crimes are known he is a 'hellish villain', a 'devil', a 'demi-devil' (5.2.284, 298, 366); and he himself invokes 'Hell and night' and the 'Divinity of hell' to bring about his schemes (1.3.345; 2.3.345).

A great deal of these characters' dramatic power derives from the audience's knowledge that they are not who they profess to be. Both are considered 'honest' - Alsemero sees his future murderer as 'kind' (Changeling 2.2.164), and Iago is a 'fellow of exceeding honesty' (Othello 3.3.262) — and only through the anagnorisis of the plays' final acts do other characters realize their mistake. Like Fitzdottrel, Othello hopes to find evidence of devilish qualities in a character's outer habit, but is disappointed when he looks at Iago: 'I look down towards his feet, but that's a fable' (5.2.283). Fitzdottrel and Othello's search for cloven hooves betray the same expectation of correspondence between exterior and interior, and their dissatisfaction is a sign of their inability to 'read' the character before them. By repeatedly invoking the language of the Fall and of the diabolic, Shakespeare and Middleton/William Rowley achieve the same effect as Jonson manages in The Devil: whether it be through language or the ambiguities of stage representation, audiences are encouraged to acquire a 'double vision' of these characters as simultaneously servile and demonic. Considering the concerns surrounding the servant figure in the period, this choice seems to be deliberate; whether the treatment of this connection achieves tragic or comic ends, dramatists clearly recognized that the cunning servant trope, associated with contemporary domestic tragedy and (especially Jonsonian) city comedy, and more distantly with the servi callidi of Roman comedy, could easily be made 'of the devil's party' as well.

After this brief survey of devil-servants and devilish-servant-types I conclude with a few observations. The first is related to the material conditions of performance in Jonson's The Devil Is an Ass, and although I do not wish to be prescriptive about whether the Pug-actor effected a 'complete' or 'partial' costume change, the play-text-as-transmitted clearly presents the sort of difficult practical questions 
that an editor can quietly raise and dismiss in a footnote but which require a clear interpretive decision when the play is staged. The Devil is full of dissemblers the Spanish Lady who charms Lady Tailbush and her salon is in fact the gallant Wittipol in disguise, and the tricksters Engine and Merecraft spend their time selling get-rich-quick schemes to the gullible — but one of the play's greatest ironies is that Fitzdottrel, a man who 'would so welcome' the Devil (1.2.45), does not even recognize one of Satan's own when he stands before him. In this regard the ambiguity surrounding Pug's appearance is more significant than previous commentators have acknowledged, because the two presentation options offer distinct effects in performance: if the change of appearance is complete, audience members may misinterpret the character at his next entrance and thus succumb to the same misreading as Fitzdottrel, and will have to supply his devilish character with their own imaginations through the course of the play; if the costume change is partial, it makes manifest the character's dual status, and the conflation of devil and servant merges these two character types together more obviously in the eyes of the audience. I have suggested that the casting of a familiar or physically striking actor may have alleviated the potential confusion between Pug-as-devil and Pug-as-servant, and although in the absence of firm evidence I would not like to press the point too firmly, the known actors I have identified would all make reasonable candidates.

When we join this observation with the reading of Iago and DeFlores, we find a repeated interest in combining the qualities of devil and servant in the works of other dramatists. The antagonists of Othello and The Changeling are certainly not the only representatives of the servile order on the early modern stage, and we only need think of Adam in As You Like It or the nameless servant who sacrifices himself defending Gloucester in King Lear to realize that dramatists staged dutiful servants as well. The playwrights considered here, however, clearly also recognized the character type had subversive potential; Iago claims that in 'following' Othello 'I follow but myself' (Othello 1.1.57), and this admission that 'service' to another is bound up with the individual's own desires reaches the heart of why servant characters could make audiences so uneasy. In Macbeth, Shakespeare offers another possible instance of the association between servant and devil when the Folio text (the only textual authority for the play) allows no exit for Seyton in 5.5 between the 'cry of women' and the servant's report that Lady Macbeth is dead ten lines later $(5.5 .8,16) .{ }^{60}$ Dessen notes that the 'logic of interpretation' often dictates that editors insert an exit and reappearance for Seyton between these lines, ${ }^{61}$ but fidelity to logic is by no means the only option 
in this scene, and indeed shuts down the interesting implications of the servant not leaving the stage:

In this rendition, the audience cannot help seeing that Seyton (to be pronounced Satan?) has no normal (earthly?) way of knowing what he knows. But he does know. Macbeth may be too preoccupied to notice the anomaly, but, if staged this way, the spectator cannot help being jarred ... Such a staging (which adds nothing but rather takes the Folio at face value) strikes me as eerie, powerful, perhaps quite unnerving. ${ }^{62}$

As with the uncertainty surrounding Pug's appearance, the reason behind Shakespeare's Seyton-Satan confusion could be as simple as the omission of a stage direction in preparing the text for publication, but curiously, whether by accident or design, both play-texts invite readers as well as audiences to wonder whether those who serve are really who they seem. In this respect Fitzdottrel — a man who 'expresses a longing to see the Devil' but also intends to go to the Blackfriars to see the very play that he is to appear in as a character (The Devil 1.2.32 sd) - stands, like Pug, as another surrogate for The Devil's theatrical and reading audiences, for by neglecting attention to this important detail of performance we too may fall into the very same act of misreading that bedevils Jonson's useless squire. 


\section{Notes}

A version of this paper was given at a seminar on 'Shakespeare and His Contemporaries' at the annual conference of the British Shakespeare Association at Queen's University, Belfast, June 2018. My thanks go to Richard Blunt, Michael Booth, Paul Frazer, Robert Hornback, Avi Mendelson, Lucy Munro, Clare McManus, Iman Sheeha, Emma Whipday, and to this journal's anonymous readers, all of whom offered invaluable suggestions on and improvements to my original draft; any errors that remain are my own.

1 Ben Jonson, Volpone, in The Cambridge Edition of the Works of Ben Jonson, ed. David D. Bevington, Martin Butler, and Ian Donaldson (Cambridge, 2012), 3.60, https:// doi.org/10.3366/bji.2013.0086. All subsequent references to Jonson's works are taken from this edition.

2 Anne Barton, Ben Jonson, Dramatist (Cambridge, 1984), 221, https://doi.org/10.1017/ CBO9780511518836.

3 John D. Cox, The Devil and the Sacred in English Drama, 1350-1642 (Cambridge, 2000), 110, https://doi.org/10.1017/CBO9780511483271.

4 Alfred Harbage thinks it likely that this text is the same as Grim the Collier of Croydon (published 1662), a view Wiggins also endorses. Harbage, Annals of English Drama, 975-1700, rev. by S. Schoenbaum, $3^{\text {rd }}$ edn (London; New York, 1989), 80; Martin Wiggins, British Drama 1533-1642: A Catalogue, 8 vols (Oxford, 2012), 4.235 .

5 Alan C. Dessen, Jonson's Moral Comedy (Evanston, Il., 1971), 235.

6 The opening scene also contains a glancing allusion to Wever's Lusty Juventus (Jonson, The Devil, 1.1.50), although the reference may have been to Marston's Historiomastix (Jonson, The Devil, 1.1.50 n, Revels edition). See also Peter Happé, 'Introduction', in Ben Jonson, The Devil Is An Ass, ed. Peter Happé (Manchester; New York), 28-9, who cites Machiavelli's Belphegor (ca 1513-17) and Nashe's Pierce Penilesse, His Supplication to the Divell (published 1592) as other likely sources for the play.

7 Christopher Marlowe, Dr Faustus: The A- and B-Texts (1604, 1616), ed. David Bevington and Eric Rasmussen (Manchester, 2014).

8 Thomas Dekker, If This Be Not a Good Play, The Devil Is in It, in The Dramatic Works of Thomas Dekker, ed. Fredson Bowers, 4 vols (Cambridge, 1958), 3.

9 Barnabe Barnes, The Devil's Charter, ed. R.B. McKerrow (Leipzig; London, 1904).

10 Brian Gibbons, Jacobean City Comedy, $2^{\text {nd }}$ edn (London; New York, 1980), 1-17, https://doi.org/10.1017/S0307883300002765.

11 Gibbons, Jacobean City, 156. 
12 Robert N. Watson, Ben Jonson's Parodic Strategy: Literary Imperialism in the Comedies (Cambridge, MA, 1987), 1, 4, https://doi.org/10.4159/harvard.9780674366510.

13 Ibid, 2.

14 For a counter view that Jonson was indifferent to including stage directions in his play-texts, see Alan C. Dessen, Elizabethan Stage Conventions and Modern Interpreters (Cambridge, 1984), 166, https://doi.org/10.1017/CBO9780511554179.

15 For more on the status and importance of the servant in the early modern period, see Mark Thornton Burnett, Masters and Servants in English Renaissance Drama and Culture: Authority and Obedience (Basingstoke; London, 1997), 1-5, https://doi. org/10.1057/9780230380141; J.A. Sharpe, Early Modern England: A Social History, 1550-1760, 2 $2^{\text {nd }}$ edn (London, 1997), 60.

16 Burnett, Masters and Servants, 1-13, 79-119.

17 Happé, 'Introduction', 20.

18 Jonson, The Devil, dramatis personae, 1-2 n.

19 Cox, The Devil and the Sacred, 157.

20 Michael Booth, Shakespeare and Conceptual Blending: Cognition, Creativity, Criticism (Cambridge, MA, 2017), 3, https://doi.org/10.1007/978-3-319-62187-6.

21 Richard Dutton, Shakespeare's Theatre: A History (Oxford, 2018), 245.

22 For good summaries of the documentary and literary evidence from the medieval to early modern periods, see Peter Happé, 'The Devil in the Interludes, 1550-1577', Medieval English Theatre 11 (1989), 42-51 (48-9); Cox, The Devil and the Sacred, 5-6; Robert Hornback, The English Clown Tradition from the Middle Ages to Shakespeare (Cambridge, 2009), 30-6. For specific examples of devils and devil costumes in play-texts between 1533 and 1631, see Wiggins, British Drama, entries 221, 472 , $810,822,888,1253,1381,1389,1392,1496,1523,1641,1645,1805,1810,1992$, 2198 , and 2332.

23 Jeffrey Burton Russell, Lucifer: The Devil in the Middle Ages (Ithaca; London, 1984), 49, 62-71, 129-158, 208-244.

24 The Merry Devil of Edmonton (Amersham, 1911).

25 Jean MacIntyre and Garrett P.J. Epp, "Cloathes Worth All the Rest”: Costumes and Properties', in A New History of Early English Drama, ed. John D. Cox and David Scott Kastan (New York, 1997), 269-285 (270). See also Philip Butterworth, Staging Conventions in Medieval English Theatre (Cambridge, 2014), 112, https://doi. org/10.1017/CBO9781139058582.

26 MacIntyre and Epp, "Cloathes Worth All the Rest”, 273.

27 See C.H. Herford, Percy Simpson, Evelyn Simpson, eds, Bed Jonson, 11 vols (Oxford, 1925-52), 10.1.3.9 n, https://doi.org/10.1093/actrade/9780198113614.book.1. 
28 See Thomas L. Berger, William C. Bradford, and Sidney L. Sondergard, An Index of Characters in Early Modern English Drama: Printed Plays, 1500-1660 (Cambridge, 1998), who identify eleven separate plays that contain cutpurses, as well as related characters including pickpockets (four entries) and thieves (thirty-three entries).

29 Compare with the devil who appears 'like a Sargeant' during the Prologue, which shows Alexander's corruption and league with Satan through dumb show (Barnes, Devil's Charter, Prologue 42).

30 R.W. Dent, Proverbial Language in English Drama Exclusive of Shakespeare, 14951616 (Berkeley and Los Angeles, 1984), see also 'As black as the devil' (D217), 'The devil is not so black as he is painted' (D255), 'Though I am black I am not the devil' (D297), 'the white devil is worse than the black' (D310).

31 Russell, Lucifer: The Devil, 129-58.

32 See Hornback, Clown, 35; Robert Hornback, Racism and Early Blackface Comic Traditions: From the Old World to the New (London, 2018), 47, https://doi. org/10.1007/978-3-319-78048-1; Virginia Mason Vaughan, Performing Blackness on English Stages, 1500-1800 (Cambridge, 2005), 1-33.

33 Vaughan, Performing Blackness, 35.

34 Richard Blunt, 'The Evolution of Blackface Cosmetics on the Early Modern Stage', in The Materiality of Colour: The Production, Circulation, and Application of Dyes and Pigments, 1400-1800, ed. Andrea Feeser, Mauren Daly Goggin, Beth Fowkes Tobin (Farnham, 2012), 229-31.

35 Vaughan, Performing Blackness, 32.

36 Blunt, 'The Evolution of Blackface', 223.

37 Hornback, Clown, 26.

38 See Annette Drew-Bear, 'Face-Painting Scenes in Ben Jonson's Plays', Studies in Philology 77.4 (1980), 401, https://doi.org/10.1086/rd.12.41917192, for a view that 'Jonson alone developed the cosmetic or fucus scene ... to dramatize his uniquely forceful vision of men and women who would seem other than indeed they are'.

39 Oxford English Dictionary (OED) Online, s.v. 'Pug, n.1', 1-2; 'Pug, n.2', 1a-b, 3, 4a, 5a.

40 If Fitzdottrel's wish for a devil in a 'brave young shape' really does allude to the Pugactor's appearance, the use of 'brave' may also suggest attractiveness. OED Online, s.v. 'Brave', $1 \mathrm{~b}$.

41 John Wilson was also a boy actor in this period, but as he seems to have worked mainly as a musician he can perhaps be discounted. See David Kathman, 'Grocers, Goldsmiths, and Drapers: Freemen and Apprentices in the Elizabethan Theatre', Shakespeare Quarterly, 55.1 (2004), 9, https://doi.org/10.1353/shq.2004.0049.

42 G.E. Bentley, The Jacobean and Caroline Stage, 2 vols (Oxford, 1941), 2.532-33.

43 Kathman, 'Grocers', 8-9. 
44 Ibid, 9-10.

45 David Kathman, 'John Rice and the Boys of the Jacobean King's Men', Shakespeare Survey 68 (2015), 247-66, https://doi.org/10.1017/CBO9781316258736.020.

46 Bentley, Jacobean and Caroline, 2.427-28.

47 Wiggins, British Drama, 6.469.

48 Kathman, 'Rice', 254.

49 Francesca Schironi, 'The Trickster Onstage: The Cunning Slave from Plautus to Commedia dell'Arte', in Ancient Comedy and Reception: Essays in Honour of Jeffrey Henderson, ed. S. Douglas Olson (New York, 2013), 447-78, https://doi. org/10.1515/9781614511250.447.

50 Cox, The Devil and the Sacred, 201-02.

51 Ibid, 205. Cox cites the anonymous The Witch of Edmonton (1621), Fletcher's The Prophetess (1622), Brome's The Queen's Exchange (1629-32), and Davenant's masque, The Temple of Love (1635) as adhering to this trend.

52 See, for example, Frances E. Dolan, Dangerous Familiars: Representations of Domestic Crime in England 1550-1700 (Ithaca; London, 1994), 4, https://doi. org/10.7591/9781501707285; Viviana Comensoli, 'Household Business': Domestic Plays of Early Modern England (Toronto, 1996), 65-6, https://doi. org/10.3138/9781442621084; Sandra Clark, The Elizabethan Pamphleteers: Popular Moralistic Pamphlets, 1580-1640 (London, 1983), 36, https://doi. org/10.5040/9781474210133.

53 Burnett, Masters and Servants, 89-93.

54 Ibid, 93.

55 The Tragedy of Master Arden of Faversham, ed. M.L. Wine (Methuen, 1973), 14.287. Emphasis mine.

56 William Shakespeare, Othello, ed. E.A.J. Honigmann, rpt. (London, 2006).

57 Critics have, of course, been keen to point out the characters' infernal links, especially to the related character of the Vice. See, amongst many others, Bernard Spivack, Shakespeare and the Allegory of Evil: The History of a Metaphor in Relation to His Major Villains (New York, 1958); Charlotte Spivack, The Comedy of Evil on Shakespeare's Stage (Rutherford, NJ, 1978); Cox, The Devil and the Sacred.

58 Burnett, Masters and Servants, 1.

59 Thomas Middleton and William Rowley, The Changeling, ed. Michael Neill, in Thomas Middleton: Four Plays (London, 2012).

60 William Shakespeare, Macbeth, ed. Sandra Clark and Pamela Mason (London, 2015).

61 Dessen, Stage Conventions, 6.

62 Ibid, 6. Emphasis in original. 